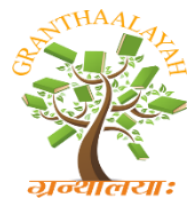

\author{
INTERNATIONAL JOURNAL OF RE
GRANTHAALAYAH \\ A knowledge Repository
}

Science

\title{
ASSESSMENT OF KNOWLEDGE, ATTITUDE AND PRACTICE (KAP) OF COMMUNITY TOWARD RABIES IN MEDAWELABU DISTRICT, BALE ZONE, ETHIOPIA
}

\author{
Derara Birasa ${ }^{1}$, Yosef Deneke ${ }^{1}$, Diriba Oljira ${ }^{1}$, Garoma Desa * \\ ${ }^{1}$ Jimma University, College of Agriculture and Veterinary Medicine, School of Veterinary \\ Medicine, P. O. Box 307, Jimma, Ethiopia
}

\begin{abstract}
The study was conducted in Meda Welabu district, Bale zone, Ethiopia from March 2019 to November 2019 to assess the knowledge, attitude and practice of the community toward rabies using a community based cross sectional study supported by semi-structured questionnaire survey. Meda Welabu district and the kebeles were selected purposively and by lottery method respectively, while the households from each kebeles were selected using systematic random sampling technique. Of 400 people interviewed, the majority of participants (88\%) had been heard of rabies previously and $52.5 \%$ of them knew dogs as the reservoir of rabies. About $73 \%$ of them answered bite is the major source of rabies transmission and $62.8 \%$ could able to describe the symptoms of rabies in dogs. Statistically significant difference was revealed between some key questions related to KAP and explanatory variables like sex $(\mathrm{P}<0.001)$, age $(\mathrm{P}<0.001)$ educational levels $(\mathrm{P}<0.001)$ and religion $(\mathrm{P}<0.001)$ of respondents. Generally, the people in this area are a little bit known about rabies; however, they have negative attitude and practice on rabies. Therefore, an education outreach should be conveyed to ensure accurate knowledge, improve attitude and practice about rabies in this area.
\end{abstract}

Keywords: Attitude; Knowledge; Meda Welabu; Practice; Rabies.

Cite This Article: Derara Birasa, Yosef Deneke, Diriba Oljira, and Garoma Desa. (2020). "ASSESSMENT OF KNOWLEDGE, ATTITUDE AND PRACTICE (KAP) OF COMMUNITY TOWARD RABIES IN MEDAWELABU DISTRICT, BALE ZONE, ETHIOPIA." International Journal of Research - Granthaalayah, 8(3), 29-42. https://doi.org/10.29121/ granthaalayah.v8.i3.2020.124.

\section{Introduction}

Rabies is a rapidly progressive and fatal viral zoonosis that causes encephalitis and caused by bullet-shaped viral particles of the genus Lyssavirus and family Rhabdoviridae, whose nucleus is RNA [1]. It is widely distributed throughout the world with the exception of Australia, New Zealand, Japan, a number of European countries and some Caribbean Islands. Wild animals serve as a large and mainly uncontrollable reservoir of sylvatic rabies, which is an increasing threat to 
the human population and to domestic animals in many countries [2]. Rabies virus causes inflammation of the brain in humans and other mammals pronounced by early symptoms of fever, tingling at the site of exposure, anorexia and change in behavior [3]. It is transmitted to humans or other animals by the bite of an infected animal whose saliva contains the virus, aerosols of the virus that can be spread in caves where bats roost, or by contamination of scratches, abrasions, open wounds and mucous membranes with saliva from an infected animal [4].

Worldwide, an estimated 29 million people receive post-exposure prophylaxis (PEP) for rabies each year and more than 59000 people die of rabies [5], primarily due to poor rabies control measures. Human rabies can be prevented through immediate administration of PEP following exposure to rabid animals [6]. However, people in low-income countries, especially the poor portion of the society, may not receive these life-saving treatments because either the PEP treatment is expensive and not readily available or people may not visit the hospital to receive treatment due to lack of knowledge about rabies [7, 8]. Rabies is endemic in developing countries of Africa and Asia and most human deaths from the disease occur in these endemic countries. Human mortality from endemic canine rabies was estimated to be 55, 000 deaths per year and was responsible for 1.74 million disability adjusted life years (DALYs) losses each year. The annual cost of rabies in Africa and Asia was estimated at US\$ 583.5 million most of which is due to cost of post exposure prophylaxis (PEP). Africa, next to Asia, is the second continent most affected by rabies with an estimated 24,000 (44\%) of the 55,000 annual rabies deaths [8]. The burden of rabies falls mostly on poor rural communities and children in particular [9].

In Ethiopia, rabies is an endemic disease with a high incidence rate that has been diagnosed from various species of domestic and wild animals [10]. However, available evidences suggest that domestic dogs are the main reservoir and responsible species for human cases in the country [11]. Despite it is a fatal disease, rabies could be prevented by the timely application of appropriate prophylaxis [9]. For increasing awareness appropriately, the knowledge gap among the community should be assessed and targeted. Public awareness and an increase of knowledge about rabies disease, first aid measures after dog bites, increased knowledge about dog behavior and how to avoid getting bitten by dogs are suggested methods to prevent rabies in humans [12]. Although rabies is primarily a disease of dogs in Ethiopia, particularly in Bale zone of Meda Welabu Woreda, no adequate research has been done to address the knowledge gab on the disease through assessing the knowledge, attitude and practice of the community toward the disease. Therefore, the main aim behind the present study was to address the current information available on rabies in the study area through assessing the gap on knowledge, attitude and practice of the community toward rabies by conducting a questionnaire survey.

\subsection{Objective of the Study}

- To assess the Knowledge, Attitude and Practice (KAP) of the community toward rabies in the study area 


\section{Materials and Methods}

\subsection{Study Area Description}

The study was conducted from March to October 2019 in Meda Welabu district, situated in Bale Zone, in the southeastern part of Oromia Region, Southeast Ethiopia. The area borders Liben district of Borena Zone to the south; Guradamole district of Bale zone to the east, Adolana district of Borena Zone to the West and Mennana Arena Buluk district of Bale Zone to the North. The altitude of Meda Welabu district ranges between 500 - 1,500 m.a.s. with two main agro-ecological zones: middle land or woina dega ranging from 1,500 - 2,000 m.a.s. and lowland or kola ranging from 500-1,500 m.a.s. Meda Welabu district has a bimodal rainy seasons. The major and most important rain falls between the mid-March to July and the second short rain comes between the ends of September to November. The population of Meda Welabu is estimated to be 82,644. They lived in scattered villages, especially in low land or Kolla areas. Today the low land is mainly characterized by mixed farming, animal rearing, as well as small scale crop cultivation, like sorghum, maiz and teff, while in the middle land or woinadega sorghum, wheat, teff and maiz are the major crops besides livestock keeping. Camels, cattle, goats, sheep and donkeys are the major animals reared in the woreda. Of all these, as in other semi-arid areas, camels and goats have great values.

\subsection{Study Population}

The people of Meda Welabu District living in randomly selected kebele were considered as the study population. The people with the age group of greater than or equal to 18 years and could freely express their ideas were enrolled in interview.

\subsection{Study Design}

Community based cross-sectional study design supported by semi-structured questionnaire survey was applied.

\subsection{Sampling and Sample Size Determination}

The required sample size for this study was estimated by considering $50 \%$ of population knowing about rabies since there was no awareness study conducted on rabies in the area before the present study. Thus, the sample size was calculated according to Thursfield, [13] using 95\% confidence interval and 5\% absolute precision. This was calculated as:

$$
\mathrm{N}=\frac{1.96^{2} \times \operatorname{Pexp}(1-\operatorname{Pexp})}{\mathrm{d}^{2}}
$$

Where,

$\mathrm{n}=$ required sample size

Pexp $=$ Expected proportion of population knowing about $(50 \%)$

$\mathrm{d} 2=$ Desired absolute precision $(5 \%)$ 
When calculated, 384 study populations were selected, but by adding 10\% non-response rates, 422 study samples were subjected. In this study, district was selected purposively based on eligible information about presence of rabies in the area and easy of transportation cost. However, probability sampling (simple random sampling) technique was conducted to select kebeles for this study. From the entire primary sampling unite, i.e., 20 kebele, five were randomly selected using lottery method. Then, systematic random sampling method was employed to select households from each kebeles for interviewing. In this study no significant variation was assumed on the number of households to be enrolled, so that equal number of households per kebele was taken. If the selected household was found locked, the next household was substituted and interviewed.

\subsection{Questionnaire Survey}

A pretested structured questionnaire consisting of closed ended questions was used for this study. The questionnaire consisted of resident profile (age, sex, education, religion) and question concerning knowledge (10questions), attitude and practice (10 questions). The questions were read out to the respondents in their local language (Afan Oromo) by the interviewer and their answers were recorded in English.

\subsection{Data Management and Analysis}

After collected, the data were coded and entered to Microsoft Excel and transport to Statistical Packages for Social Science (SPSS) version 23.0 statistical packages for windows and analysis was made. Descriptive statics was employed on variables of interest. Association between sociodemographic characteristics (explanatory variables) and KAP of community on rabies was calculated using Pearson's Chi square test. All P value of less than 5\% was considered as statistical significance.

\section{Result}

\subsection{Socio-Demographic Characteristics}

In this study, 422 heads of households were subjected to be interviewed, however, after complete check up only the response of 400 households were enrolled to be analyzed. From 20 kebele, 5 kebele were selected randomly by assuming equal proportion of households per kebele. Therefore, 80 households were selected from each kebele to be interviewed in face to face (table 1).

From 400 respondents, $70 \%$ were male and $30 \%$ of them were females. The age groups between 18-30 years accounted the highest proportion (50\%) of all age categories. Concerning level of education, the majority of respondents were illiterate (37.5\%) and Muslims were accounted for the highest number $(62.5 \%)$ among their religion (table 1$)$.

Table 1: Description of Socio-demographic variables

\begin{tabular}{|c|c|c|}
\hline Socio-demographic characteristics & Frequency & Percent \\
\hline Kebele & & $100 \%$ \\
\hline Waduma & 80 & $20 \%$ \\
\hline Kerjul & 80 & $20 \%$ \\
\hline
\end{tabular}




\begin{tabular}{|c|c|c|}
\hline Aba sirba & 80 & $20 \%$ \\
\hline $\begin{array}{c}\text { Oborshow } \\
\text { Medda }\end{array}$ & 80 & $20 \%$ \\
Sex $\quad 80$ & $20 \%$ \\
\hline Male & & \\
\hline Female & 280 & $70 \%$ \\
\hline Age $\quad 120$ & $30 \%$ \\
\hline < 18 year & & \\
\hline $18-30$ year & 50 & $12.5 \%$ \\
\hline$>30$ year & 200 & $50 \%$ \\
\hline Educational level & 150 & $37.5 \%$ \\
\hline Illiterate & & \\
\hline Primary & 150 & $37.5 \%$ \\
\hline High school & 60 & $15 \%$ \\
\hline College/university & 94 & $23.5 \%$ \\
\hline Religion & 96 & $24 \%$ \\
\hline Muslim & 250 & $62.5 \%$ \\
\hline Christians & 50 & $12.5 \%$ \\
\hline Traditional & 80 & $20 \%$ \\
\hline No religion & 20 & $5 \%$ \\
\hline
\end{tabular}

\subsection{Knowledge of Respondents Toward Rabies}

The majority of participants $(88 \%)$ had been heard of rabies previously and the highest proportion $(52.5 \%)$ of them knew dogs as the reservoir of rabies whilst the lowest number of them (10\%), knew cats were the reservoir of rabies. Similarly, the majority of participants (73.8) knew that rabies is fatal disease, $14.8 \%$ of them answered as they were not sure as rabies is fatal whereas the smallest number $(11.5 \%)$ of them didn't know as rabies is fatal. The largest percentage $(39.8 \%)$ of respondents didn't know as vaccine prevents rabies, whereas $37.8 \%$ of them knew as rabies can be prevented by vaccine and $22.5 \%$ were not sure whether vaccine prevents or not.

Most respondents obtained about rabies from different sources. The highest percentages (48\%) of them were informed about rabies from several sources, $32.8 \%$ were informed from health professionals, whereas $19.2 \%$ were heard from radio/Television. About seventy three percent of respondents understood the mode of transmission of rabies through biting whereas $15 \%$ and $11.5 \%$ of them knew the means of rabies transmission through fluid contacting and scratching respectively. Sixty eight percent of respondents were in favor of describing the symptoms of rabies in dogs while $32.8 \%$ of them could not able to describe the symptoms of rabies in dogs.

Since most of the people living in the villages of Ethiopia were close to each other, they know about events happening in their nearby households. In this study, about seventy four percentage of respondents had seen a person bitten by a rabid dog and 55.3\% reported bitten on the leg among parts of the body. From the people bitten they had ever seen children were accounted for the highest proportion $(48.8 \%$ ) where people with old age shared $9.3 \%$ from the bitten people they had seen. 
Table 2: Response of participants pertaining to their knowledge toward rabies

\begin{tabular}{|c|c|c|}
\hline Questions concerning knowledge of respondents $(N=400)$ & Frequency & Percentage \\
\hline \multicolumn{3}{|l|}{ Have you ever heard of rabies? } \\
\hline Yes & 352 & $88 \%$ \\
\hline No & 48 & $12 \%$ \\
\hline \multicolumn{3}{|l|}{ Main reservoir of rabies } \\
\hline Dog & 210 & $52.5 \%$ \\
\hline Cat & 40 & $10 \%$ \\
\hline Fox & 90 & $22.5 \%$ \\
\hline Other & 60 & $15 \%$ \\
\hline \multicolumn{3}{|l|}{ Rabies is fatal } \\
\hline Yes & 295 & $73.8 \%$ \\
\hline No & 46 & $11.5 \%$ \\
\hline I am not sure & 59 & $14.8 \%$ \\
\hline \multicolumn{3}{|l|}{ Rabies can be prevented by vaccination } \\
\hline Yes & 151 & $37.8 \%$ \\
\hline No & 159 & $39.8 \%$ \\
\hline I am not sure & 90 & $22.5 \%$ \\
\hline \multicolumn{3}{|l|}{ Source information about rabies } \\
\hline Health professional & 131 & $32.8 \%$ \\
\hline Radio/TV & 77 & $19.2 \%$ \\
\hline Other & 192 & $48 \%$ \\
\hline \multicolumn{3}{|l|}{ Mode of transmission of rabies } \\
\hline Bite & 294 & $73.5 \%$ \\
\hline Fluid contact & 60 & $15 \%$ \\
\hline Scratch & 46 & $11.5 \%$ \\
\hline \multicolumn{3}{|l|}{ Could you describe symptoms of rabies in dogs } \\
\hline Yes & 273 & $68.2 \%$ \\
\hline No & 127 & $31.8 \%$ \\
\hline \multicolumn{3}{|l|}{ Have you ever seen a person bitten by rabid dog } \\
\hline Yes & 299 & $74.8 \%$ \\
\hline No & 101 & $25.2 \%$ \\
\hline \multicolumn{3}{|l|}{ Describe a site of bite of a person you ever seen } \\
\hline Leg & 221 & $55.3 \%$ \\
\hline Hand & 70 & $17.5 \%$ \\
\hline Head & 8 & $2 \%$ \\
\hline I haven't seen & 101 & $25.2 \%$ \\
\hline \multicolumn{3}{|l|}{ Age of bitten person } \\
\hline Children & 195 & $48.8 \%$ \\
\hline Young & 67 & $16.8 \%$ \\
\hline Old & 37 & $9.3 \%$ \\
\hline
\end{tabular}




\subsection{Attitude and Practice of Respondents Toward Rabies}

In the same manner, 400 respondents were enrolled to assess the attitude and practice of the people toward rabies. A higher proportion of participants (85\%) had negative practice on reporting to the authorities if they were bitten by dogs while smaller proportion had positive practice (15\%). Similarly, seventy-five percentage of interviewed people had negative response on reporting to the authorities if they had seen rabid dog. The majority of them $(85.8 \%)$ agreed with the idea that killing rabies suspected stray dogs as solution to control rabies and smaller number (14.2\%) had negative practice. About fifty-two percentage of respondents answered as they would not eat a milk or meat from rabid cow or bull whereas $47.5 \%$ eat as usual without boiling or cooking. The highest proportion of respondents $(63.5 \%)$ had negative attitude on the idea that suggests the stray dog plays a role in abundance of rabies (table 3 )

The study also showed that $47.8 \%$ of the respondents had negative attitude on vaccination prevent rabies in dogs, about $27 \%$ had positive attitude and $25 \%$ didn't know whether it prevent or not. About $45 \%$ of respondents believed control of rabies should involve all social structures, government and non-government bodies while the smallest proportion (5.8\%) had an attitude as NGO should have to control rabies independently.

Among pets owned by the respondents, dogs were accounted for higher proportions (55.3\%) while cats were owned by $6.5 \%$ and $10.2 \%$ respondents owned both dogs and cats. In this study, majority of the people $(66.8 \%)$ had no practice of vaccinating their pets and smaller proportion (5.2\%) vaccinated their pets within last 12 months (table 3 )

Table 3: Descriptions of attitude and practice of respondents toward rabies

\begin{tabular}{|l|c|c|}
\hline Questions related to Attitude and practice of respondents & Frequency & Percent \\
\hline Would you inform the authorities if you were bitten by dog? & & \\
\hline Yes & 60 & $15 \%$ \\
\hline No & 340 & $85 \%$ \\
\hline Would you report to authorities if you see rabid dog? & & \\
\hline Yes & 100 & $25 \%$ \\
\hline No & 300 & $75 \%$ \\
\hline Would you kill rabies suspected stray dogs? & 343 & $85.8 \%$ \\
\hline Yes & 57 & $14.2 \%$ \\
\hline No & & \\
\hline Would you eat milk or a meat from rabid cow or bull? & 190 & $47.5 \%$ \\
\hline Yes, as usual & 210 & $52.5 \%$ \\
\hline No & & \\
\hline Do you think stray dog play a role in abundance of rabies? & 146 & $36.5 \%$ \\
\hline Yes & 254 & $63.5 \%$ \\
\hline No & & \\
\hline Do you think vaccination prevent rabies in dogs?
\end{tabular}




\begin{tabular}{|c|c|c|}
\hline Yes & 109 & $27.2 \%$ \\
\hline No & 191 & $47.8 \%$ \\
\hline I don't know & 100 & $25 \%$ \\
\hline Who is responsible to control rabies in stray dogs? & & \\
\hline Government & 97 & $24.2 \%$ \\
\hline NGO & 23 & $5.8 \%$ \\
\hline Community & 100 & $25 \%$ \\
\hline All & 180 & $45 \%$ \\
\hline Which species of pet do you owned? & & \\
\hline Dog & 221 & $55.3 \%$ \\
\hline Cat & 26 & $6.5 \%$ \\
\hline Both & 41 & $10.2 \%$ \\
\hline No pet & 112 & $28 \%$ \\
\hline How many pet do you owned? & 245 & $61.3 \%$ \\
\hline One & 43 & $10.7 \%$ \\
\hline Two and above & 112 & $28 \%$ \\
\hline No pet & & \\
\hline Did you vaccinate them with in last 12 months? & 21 & $5.2 \%$ \\
\hline Yes & 267 & $66.8 \%$ \\
\hline No & 112 & $28 \%$ \\
\hline No pet & & \\
\hline
\end{tabular}

\subsection{Association of KAP and Socio-Demographic Characteristics}

In the present study, seven questions pertaining to knowledge and seven questions regarding attitude and practice were asked to assess the knowledge, attitude and practice of respondents about rabies. The association between independent variables (sex, age, education level and religion) and the questionnaire survey was performed using chi-square test of association.

The study revealed that, questions concerned knowledge (aware about rabies, main reservoir of rabies, rabies fatal, rabies can be prevented by vaccination, source of information about rabies, descriptions of symptoms of rabies in dog) were highly statistically significant $(\mathrm{P}<0.05)$ with sex, age, educational level and religion of respondents(table 4). However, there was no statistically significant variation $(\mathrm{P}>0.05)$ between question related to mode of transmission of rabies and socio-demographic variables.

In the same way, there was statistically significant association $(\mathrm{P}<0.05)$ between independent variables (age, educational level and religion) and attitude and practice of respondents toward rabies (question regarding reporting to authorities if they see rabid dog, stray dog play a role in abundance of rabies, vaccination prevent rabies in dogs, vaccinated their pets within last 12 months). Statistically significant variation $(\mathrm{P}<0.05)$ was observed between eating habit of respondents (milk or meat from rabid cow or bull) and their sex and religion. However, no significant variation was observed among sex, age and educational level of respondents regarding 
their attitude and practice on informing if they bitten by dog and reporting to authorities if they see rabid dog. The detailed description was given in table 4 .

Table 4: The association between KAP and socio-demographic variables

\begin{tabular}{|c|c|c|c|c|c|c|c|c|c|c|c|c|c|c|c|c|c|}
\hline \multirow{2}{*}{$\begin{array}{l}\text { Questions related } \\
\text { to Knowledge of } \\
\text { respondents }\end{array}$} & \multicolumn{3}{|c|}{$\operatorname{Sex}(\%)$} & \multicolumn{4}{|c|}{ Age in year (\%) } & \multicolumn{5}{|c|}{ Education level (\%) } & \multicolumn{5}{|c|}{ Religion (\%) } \\
\hline & 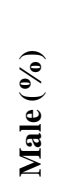 & 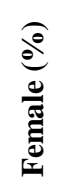 & 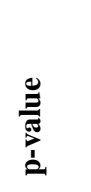 & $\frac{d}{\sqrt{e}}$ & 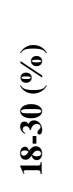 & 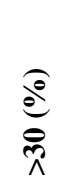 & 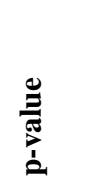 & 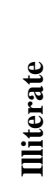 & 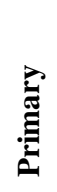 & 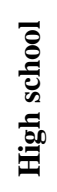 & 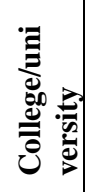 & 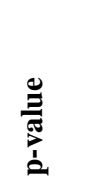 & $\stackrel{\Xi \Xi}{\stackrel{\Xi}{\Xi}}$ & : & : & 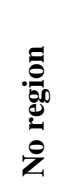 & 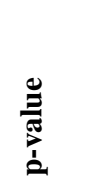 \\
\hline \multicolumn{18}{|l|}{$\begin{array}{l}\text { Have you ever } \\
\text { heard of rabies? }\end{array}$} \\
\hline Yes & 92.9 & 76.7 & 0.000 & 100 & 100 & 68 & 0.000 & 68 & 100 & 100 & 100 & 0.000 & 100 & 100 & 65 & 0 & 0.005 \\
\hline No & 7.1 & 23.3 & & 0 & 0 & 32 & & 32 & 0 & 0 & 0 & & 0 & 0 & 35 & 20 & \\
\hline \multicolumn{18}{|l|}{$\begin{array}{l}\text { Main reservoir of } \\
\text { rabies }\end{array}$} \\
\hline Dog & 53.2 & 50.8 & 0.000 & 100 & 80 & 0 & 0.000 & 0 & 100 & 100 & 58.3 & 0.000 & 84 & 0 & 0 & 0 & 0.000 \\
\hline Cat & 11.4 & 6.7 & & 0 & 20 & 0 & & 0 & 0 & 0 & 41.7 & & 16 & 0 & 0 & 0 & \\
\hline Fox & 28.2 & 9.2 & & 0 & 0 & 60 & & 40 & 0 & 0 & 0 & & 0 & 100 & 50 & 0 & \\
\hline Other & 7.1 & 33.3 & & 0 & 0 & 40 & & 60 & 0 & 0 & 0 & & 0 & 0 & 50 & 100 & \\
\hline \multicolumn{18}{|l|}{ Rabies is fatal } \\
\hline Yes & 73.6 & 74.2 & 0.005 & 28 & 93.5 & 62.7 & 0.000 & 63 & 40 & 86 & 100 & 0.000 & 80.4 & 48 & 72.5 & 60 & 0.000 \\
\hline No & 14.3 & 5 & & 36 & 0 & 18.7 & & 19 & 30 & 0 & 0 & & 7.2 & 28 & 7.5 & 40 & \\
\hline $\begin{array}{ll}\text { I am not } \\
\text { sure }\end{array}$ & 12.1 & 20.8 & & 36 & 6.5 & 18.7 & & 18 & 30 & 14 & 0 & & 12.4 & 24 & 20 & 0 & \\
\hline \multicolumn{18}{|l|}{$\begin{array}{l}\text { Rabies can be } \\
\text { prevented by } \\
\text { vaccination }\end{array}$} \\
\hline Yes & 43.6 & 24.2 & 0.001 & 18 & 64 & 9.3 & 0.000 & 9 & 32 & 69 & 55 & 0.000 & 54.8 & 16 & 5 & 10 & 0.000 \\
\hline No & 36 & 48.3 & & 54 & 10 & 74.7 & & 75 & 45 & 8 & 14 & & 18.8 & 58 & 83.8 & 80 & \\
\hline $\begin{array}{ll}\text { sure } & \text { I am not }\end{array}$ & 20.4 & 27.5 & & 28 & 26 & 16 & & 16 & 23 & 23 & 31 & & 26.4 & 26 & 11.2 & 10 & \\
\hline \multicolumn{18}{|l|}{$\begin{array}{l}\text { Source information } \\
\text { about rabies }\end{array}$} \\
\hline $\begin{array}{l}\text { Health } \\
\text { professional }\end{array}$ & 29.3 & 40.8 & 0.000 & 12 & 45 & 23.3 & 0.000 & 23 & 12 & 66 & 28 & 0.000 & 38.4 & 38 & 15 & 20 & 0.000 \\
\hline Radio/TV & 24.6 & 6.7 & & 50 & 10.5 & 20.7 & & 21 & 46 & 6 & 13 & & 18.4 & 44 & 7.5 & 15 & \\
\hline Other & 46.1 & 52.5 & & 38 & 44.5 & 56 & & 56 & 42 & 28 & 59 & & 43.2 & 18 & 77.5 & 65 & \\
\hline \multicolumn{18}{|l|}{$\begin{array}{l}\text { Mode of } \\
\text { transmission of } \\
\text { rabies }\end{array}$} \\
\hline Bite & 74.3 & 71.7 & 0.858 & 70 & 73 & 75.3 & 0.751 & 75 & 70 & 68 & 78 & 0.763 & 72.8 & 74 & 76.3 & 75 & 0.958 \\
\hline $\begin{array}{ll} & \text { Fluid } \\
\text { contact } & \\
\end{array}$ & 14.6 & 15.8 & & 20 & 14 & 14.7 & & 15 & 17 & 18 & 12 & & 15.2 & 16 & 15 & 10 & \\
\hline Scratch & 11.1 & 12.5 & & 10 & 13 & 10 & & 10 & 13 & 14 & 10 & & 12.4 & 10 & 8.7 & 15 & \\
\hline \multicolumn{18}{|l|}{$\begin{array}{l}\text { Describe } \\
\text { symptoms of rabies } \\
\text { in dogs }\end{array}$} \\
\hline Yes & 62.1 & 82.5 & 0.000 & 38 & 72 & 73.3 & 0.000 & 73 & 40 & 66 & 80 & 0.000 & 65.2 & 52 & 81.2 & 95 & 0.000 \\
\hline No & 37.9 & 17.5 & & 62 & 28 & 26.7 & & 27 & 60 & 34 & 20 & & 34.8 & 48 & 18.8 & 5 & \\
\hline \multicolumn{18}{|l|}{$\begin{array}{l}\text { Attitude and } \\
\text { practice of } \\
\text { respondents }\end{array}$} \\
\hline \multicolumn{18}{|l|}{$\begin{array}{l}\text { Would you inform } \\
\text { if bitten by dog? }\end{array}$} \\
\hline Yes & 16 & 13 & 0.541 & 24 & 12.5 & 15.3 & 0.124 & 15 & 22 & 14 & 12 & 0.369 & 15 & 12 & 15 & 25 & 0.587 \\
\hline No & 84 & 87 & & 76 & 87.5 & 84.7 & & 85 & 78 & 86 & 88 & & 85 & 88 & 75 & 75 & \\
\hline
\end{tabular}




\begin{tabular}{|c|c|c|c|c|c|c|c|c|c|c|c|c|c|c|c|c|c|}
\hline \multicolumn{18}{|c|}{$\begin{array}{l}\text { Would you report } \\
\text { to authorities if you } \\
\text { see rabid dog? }\end{array}$} \\
\hline Yes & 25 & 24 & 0.801 & 18 & 28.5 & 22.7 & 0.218 & 23 & 18 & 33 & 25 & 0.168 & 26 & 44 & 14 & 5 & 0.000 \\
\hline No & 75 & 76 & & 82 & 71.5 & 77.3 & & 77 & 82 & 67 & 75 & & 74 & 56 & 86 & 95 & \\
\hline \multicolumn{18}{|c|}{$\begin{array}{l}\text { Would you eat milk } \\
\text { or a meat from } \\
\text { rabid cow or bull? }\end{array}$} \\
\hline $\begin{array}{ll}\text { usual } & \text { Yes, as } \\
\end{array}$ & 44.3 & 55 & 0.049 & 42 & 53.5 & 41.3 & 0.056 & 41 & 43 & 50 & 57 & 0.085 & 51 & 16 & 56 & 45 & 0.000 \\
\hline No & 55.7 & 45 & & 58 & 46.5 & 58.7 & & 59 & 57 & 50 & 43 & & 49 & 84 & 44 & 55 & \\
\hline \multicolumn{18}{|l|}{$\begin{array}{l}\text { Do you think stray } \\
\text { dog play a role in } \\
\text { abundance of } \\
\text { rabies? }\end{array}$} \\
\hline Yes & 36.8 & 35.8 & 0.856 & 40 & 45 & 24 & 0.000 & 24 & 40 & 46 & 45 & 0.001 & 44 & 30 & 21 & 20 & 0.001 \\
\hline No & 63.2 & 64.8 & & 60 & 55 & 76 & & 76 & 60 & 54 & 55 & & 56 & 70 & 79 & 80 & \\
\hline \multicolumn{18}{|c|}{$\begin{array}{l}\text { Do you think } \\
\text { vaccination prevent } \\
\text { rabies in dogs? }\end{array}$} \\
\hline Yes & 27.9 & 25.8 & 0.720 & 30 & 36 & 14.7 & 0.000 & 15 & 25 & 35 & 40 & 0.000 & 35 & 16 & 10 & 30 & 0.000 \\
\hline No & 46.4 & 50.8 & & 36 & 40 & 62 & & 62 & 35 & 45 & 37 & & 39 & 60 & 65 & 55 & \\
\hline know I don't & 25.7 & 23.3 & & 34 & 24 & 23.3 & & 23 & 40 & 20 & 23 & & 26 & 24 & 25 & 15 & \\
\hline \multicolumn{18}{|c|}{$\begin{array}{l}\text { Did you vaccinate } \\
\text { them with in last } 12 \\
\text { months? }\end{array}$} \\
\hline Yes & 6.4 & 5.8 & 0.661 & 0 & 4.5 & 10.7 & 0.017 & 11 & 2 & 1 & 7 & 0.021 & 4 & 12 & 8 & 20 & 0.003 \\
\hline No & 65.4 & 70 & & 80 & 68 & 60.7 & & 60 & 78 & 68 & 68 & & 70 & 48 & 71 & 50 & \\
\hline No pet & 28.2 & 24.2 & & 20 & 27.5 & 28.7 & & 29 & 20 & 31 & 25 & & 26 & 40 & 21 & 30 & \\
\hline
\end{tabular}

\section{Discussion}

The finding of the present study revealed, majority of the people (88\%) heard about rabies previously and dogs were mentioned as the major reservoir host $(52.5 \%)$ for rabies among other animals. Similarly, the majority of participants (73.8) knew that rabies is fatal disease and the largest percentage (39.8\%) of respondents didn't know as vaccine prevents rabies. this result was in line with the study conducted in Sri lank and Jammu, India [14, 15].

The highest percentages (48\%) of respondents were informed about rabies from multiple sources, $32.8 \%$ were informed from health professionals, whereas $19.2 \%$ were heard from radio/Television. This result was in line with the study conducted in Sri Lanka [14]. About seventy three percent of respondents understood the mode of transmission of rabies through biting whereas $15 \%$ and $11.5 \%$ of them knew the means of rabies transmission through fluid contacting and scratching respectively. This was in consistent with other study conducted in Sixty eight percent of respondents were in favor of describing the symptoms of rabies in dogs while $32.8 \%$ of them could not able to describe the symptoms of rabies in dogs. This study was in agreement with the finding of the study conducted in Sri Lanka and in south Gondar [14, 16]. From the people bitten they had ever seen in their area, children were accounted for the highest proportion (48.8\%) while a few number of people $(9.3 \%)$ with old age were involved. This was in agreement with the study conducted in Nigeria [17]. 
A higher proportion of participants (85\%) had negative practice on reporting to the authorities if they were bitten by dogs while smaller proportion had positive practice (15\%). This was in contrary with the study conducted by Ali et al. [18] in and around Addis Ababa and in Sri Lanka [14]. Similarly, seventy five percent of interviewed people had negative response on reporting to the authorities if they had seen rabid dog. The majority of them $(85.8 \%)$ agreed with the idea that killing rabies suspected stray dogs as solution to control rabies and smaller number (14.2\%) had negative practice. This finding was in consistent with the study conducted in Dessie city [19], but in contrary with the study conducted in Jammu, India who reported the people that areas were alerted to report to concern body if they saw the stray dogs and bitten [15].

The result of current study has also revealed that the majority $(47.8 \%)$ of the respondents had negative attitude on vaccination prevent rabies in dogs, about $27 \%$ had positive attitude and $25 \%$ didn't know whether it prevent or not. This was disagreeing with the finding of Tolessa and Mengistu, [20] in and around Nekemte town. The negative attitude of the people in this study might be resulted from lack of awareness on importance of vaccinating the pets due to in adequate health education and in adequate availability of vaccine in the areas. Among pet owners interviewed in this study, dogs were accounted for higher proportions (55.3\%) while cats were owned by $6.5 \%$ and $10.2 \%$ respondents owned both dogs and cats. This finding was nearly consistent with the study conducted in Bangladesh Ghosh et al. [21] who reported the highest proportion of dog owners among the community interviewed. In this study, majority of the people $(66.8 \%)$ had no practice of vaccinating their pets and smaller proportion (5.2\%) vaccinated their pets within last 12 months. This result was disagreeing with the study conducted in Sri Lanka Matibag et al. [14] and in and around Nekemte town by Tolessa and Mengistu, [20].

The result of current study showed that independent variables like sex, age, educational status and religion of respondents were statistically $(\mathrm{P}<0.05)$ associated with the knowledge of respondents toward rabies. The study indicated that males shared higher proportion (92.9\%) of hearing about rabies from several sources than female. Similarly, the larger number of male respondents knew as rabies was prevented by vaccination compared to female respondents. In this study female shared higher percentage of hearing about rabies from health professionals than males although higher proportions of male respondents heard from different sources. This might be resulted from females had high opportunity to get adequate health education from health extensions than males. The higher proportions of male respondents could able to describe the symptoms of rabies in rabid dogs compared to females. Generally, there was statistically significant variation among sex of respondents on their knowledge toward rabies. The variation might be resulted from the higher opportunity of males to obtain knowledge about rabies from different sources through exposure to meeting, idea exchange with the community and at the work place due to the nature of their work. This finding was consistent with the study conducted elsewhere in Ethiopia, south Gondar by Alie et al. [16] and in Bahir Dar town by Guadu et al. [22] but contrary with the study conducted in Nekemte town by Tolessa and Mengistu, [20].

In addition, age and educational level of respondents were statistically associated $(\mathrm{P}<0.05)$ with knowledge of respondents (table 4). This was supported by the study conducted among residents in Addis Ababa by Ali et al. [18]; in south Gondar Alie et al. [16] and in Bahir Dar town by Guadu et al. [22]. The difference in age groups on knowledge toward rabies might be due to the fact that the age groups below 18 years were unable to obtain sufficient information about rabies since they 
were teenagers while other age groups had high opportunity to know about rabies through formal and informal education. Religion was also significantly associated with knowledge of respondents as indicated in table 4 . In this study respondents with no religion were a little bit knowledgeable than others. This was due to give low attention to rabies because of believing rabies has no power to intent harm if pray. This was in contrary with the study conducted in Nekemte town [20].

Pertaining to attitude and practice, statistically sex wise variation was observed among respondents on the eating habits of milk or meat from rabid cow or bull. About $55 \%$ of female respondents answered that eating milk or meat without boiling or cooking as usual has no effect on rabies transmission. However, some literature suggested that, unless milk is well boiled, there is a risk of rabies exposure, particularly in children. According to a paper submitted at the last Indian Virology Conference, tests Conducted on the brains of slaughtered cattle and sheep showed that an alarming two per cent of them contained rabies virus [23].

Similarly, age, educational levels and religion of respondents were significantly associated $(\mathrm{p}<0.05)$ with attitude and practice of respondents (table 4$)$. The age groups 18- 30 years were accounted for $45 \%$ in responding that, the stray dog play a role in abundance of rabies. Although low percentage of response was obtained on the question vaccine can prevent rabies across all age groups, a little difference was seen with in age 18-30 years (36\%). The significant variation in these age groups might be resulted from the age groups 18- 30 years had high likelihoods to obtain sufficient information about rabies from formal learning at school in addition to what they shared from events happening in their community compared to other age groups. This finding was nearly similar with the same study conducted in Nekemte town [20] and in Bahir Dar town [22].

Attitude and practice of the respondents were also significantly associated with their educational level. There was statistically significant variation on the answers of respondents regarding the questions whether the stray dog play a role in abundance of rabies, vaccination prevent rabies and vaccinated their dogs with in last 12 months $(\mathrm{P}<0.05)$ which was illustrated in table 4 . A higher proportion on the questions regarding, the stray dogs play a role in abundance of rabies and vaccination prevents rabies was observed in respondents who had high school and college/university education level. The clear explanation of positive attitude and practice regarding rabies in respondents with greater than high school education level was that educated person could have better information and understanding and give due attention bout rabies. This finding was supported by the study conducted in Sri lank and Jammu, India by Matibag et al. [14]; Tandon et al. [15]; in Bangladesh Ghosh et al. [21] and Bahir Dar town by Guadu et al. [22].

\section{Conclusions and Recommendations}

The present study revealed that, the people in this area are aware of rabies before and they are a little bit knowledgeable on main reservoir of rabies, as rabies is a fatal disease, mode of transmission and could able to describe the symptoms of rabies in dog. However, there is huge gap on attitude and practice on rabies in general regarding informing the authorities if they are bitten by rabid dog, encountered rabid dog, and rabies would be prevented by vaccination and vaccinating their dog against vaccine. Based on the above conclusion, the following recommendations are forwarded; 
- The outreach education is needed to insure accurate knowledge and to improve the attitude and practice of the community in this area.

- The concerning body, in particular, veterinarians and health professionals, should have to aware of the community the impact of the disease, so that seeking immediate post exposure treatment on time if exposed unknowingly to culminate an necessary death

- Pet owners should have to get adequate education from both veterinary professional and human health sector on the importance of vaccine against rabies so that interested to vaccinate their dog pets.

- Public health sectors, veterinary sectors and other stakeholders should work together to prevent and control the public health and economic impact of rabies

- Livestock owners should have to get adequate information to prevent their animals from exposure

\section{References}

[1] Gemechu, R., 2017. Review on Economic Importance's of Rabies in Developing Countries and Its Controls. Arch Prev Med, 2(1), pp.015-021.

[2] Moges, N., 2015. Epidemiology, prevention and control methods of human rabies. Intl J Basic \& Appl Virol, 4(1), pp.22-27.

[3] World Health Organization, 2013. WHO expert consultation on rabies: second report (Vol. 982). World Health Organization

[4] Levinson, W., 2004. Medical Microbiology and Immunology. 8th ed. United States: McGraw Hill, pp: 271-272.

[5] Hampson, K., Coudeville, L., Lembo, T., Sambo, M., Kieffer, A., Attlan, M., Barrat, J., Blanton, J.D., Briggs, D.J., Cleaveland, S. and Costa, P., 2015. Estimating the global burden of endemic canine rabies. PLoS neglected tropical diseases, 9(4), p.e0003709.

[6] Hemachudha, T., Laothamatas, J. and Rupprecht, C.E., 2002. Human rabies: a disease of complex neuropathogenetic mechanisms and diagnostic challenges. The Lancet Neurology, 1(2), pp.101109.

[7] Kayali, U., Mindekem, R., Yemadji, N., Oussiguere, A., Na1ssengar, S., Ndoutamia, A.G. and Zinsstag, J., 2003. Incidence of canine rabies in N'Djamena, Chad. Preventive veterinary medicine, 61(3):.227-233.

[8] Knobel, D.L., Cleaveland, S., Coleman, P.G., Fèvre, E.M., Meltzer, M.I., Miranda, M.E.G., Shaw, A., Zinsstag, J. and Meslin, F.X., 2005. Re-evaluating the burden of rabies in Africa and Asia. Bulletin of the World health Organization, 83, pp.360-368.

[9] World Health Organization, 2005. Consultation on Rabies: first report. WHO Technical Report Series, 931.

[10] Jemberu, W.T., Molla, W., Almaw, G. and Alemu, S., 2013. Incidence of rabies in humans and domestic animals and people's awareness in North Gondar Zone, Ethiopia. PLoS neglected tropical diseases, 7(5), p.e2216.

[11] Deressa, A., Ali, A., Bayene, M., Selassie, B.N., Yimer, E. and Hussen, K., 2010. The status of rabies in Ethiopia: A retrospective record review. Ethiopian Journal of Health Development, 24(2).

[12] Nilsson, M., 2014. Effect of rabies education programs on rabies awareness, attitudes toward dogs and animal welfare among children in Lilongwe, Malawi.

[13] Thursfield, M., 2005. Survey in Veterinary Epidemiology. 2nd ed. Uk: Blackwell Science, Limited, Cambridge, pp: 297-302.

[14] Matibag, G.C., Kamigaki, T., Kumarasiri, P.V., Wijewardana, T.G., Kalupahana, A.W., Dissanayake, D.A., De Silva, D.N., Gunawardena, G.P.D.S., Obayashi, Y., Kanda, K. and 
Tamashiro, H., 2007. Knowledge, attitudes, and practices survey of rabies in a community in Sri Lanka. Environmental health and preventive medicine, 12(2), pp.84-89.

[15] Tandon, S., Kotwal, S.K., Malik, M.A., Singh, M., Kumar, D., Shafiq, M. and Kumar, M., 2017. A community based survey on rabies control and prevention using KAP in Jammu, India. Journal of Animal Research, 7(6), pp.1019-1028.

[16] Alie, A., Assefa, A., Derso, S. and Ayele, B., 2015. Assessment of knowledge, attitude and practice on rabies in and around Debretabor, South Gondar, Northwest Ethiopia. Int J Basic Appl Virol, 4(1), pp.28-34.

[17] Ayodele, J.O., 2014. Support for Victims of Crime in Lagos, Nigeria. Editor's Comments, 7(3), pp.24-44.

[18] Ali, A., Ahmed, E.Y. and Sifer, D., 2013. A Study on Knowledge, Attitude and Practice of rabies among residents in Addis Ababa, Ethiopia. Ethiopian Veterinary Journal, 17(2), pp.19- 35.

[19] Gebeyaw, S. and Teshome, D., 2016. Study on Community Knowledge, Attitude and Practice of Rabies in and Around Dessie City. Austin J. Vet. Sci. Anim. Husb, 3(1), p.1020.

[20] Tolessa, T. and Mengistu, A., 2017. Knowledge of rabies in and around Nekemte Town, Ethiopia. Journal of Public Health and Epidemiology, 9(9), pp.244-250.

[21] Ghosh, S., Chowdhury, S., Haider, N., Bhowmik, R.K., Rana, M.S., Prue Marma, A.S., Hossain, M.B., Debnath, N.C. and Ahmed, B.N., 2016. Awareness of rabies and response to dog bites in a Bangladesh community. Veterinary medicine and science, 2(3), pp.161-169.

[22] Guadu, T., Shite, A., Chanie, M., Bogale, B. and Fentahun, T., 2014. Assessment of knowledge, attitude and practices about rabies and associated factors: in the case of Bahir Dar town. Global Veterinaria, 13(3), pp.348-54.

[23] Kaur, R., 2017. IS RABIES TRANSMISSABLE THROUGH MILK?. GSJ, 5(11), p.105.

*Corresponding author.

E-mail address: garomadesa@y yhoo.com 